\title{
2010-2017 Yılları Arasında Türkiye'de Matematik Eğitimi Alanında Yapılan Lisansüstü Tezlerin İncelenmesi
}

\section{Comparative Analysis of Post-Graduate Theses Conducted Between the Years 2010-2017 In the Field of Mathematics Education In Turkey According to Certain Standards}

\section{$\underline{\text { Anahtar Kelimeler }}$ Matematik ĕgitimi Matematik ögretimi Meta-analitik Lisansüstü tezler}

\author{
Abdullah TERECI ${ }^{1}$ Recep BINDAK ${ }^{2}$
}

\section{$\ddot{O}_{z e t}$}

Bu çalıșma 2010-2017 yılları arasında Matematik Eğitimi alanında yazılan lisansüstü tezlerini üniversite, yıl, cinsiyet, dil, araştırma türü, araştırma modeli, ögrenme alanı, inceleme alanı, veri toplama araçları, kullanılan istatistiksel teknikler, örneklem değişkenleri açısından karşılaştırmalı incelemek amacıyla yapılmıştır. Araştırmanın örneklemini YÖK veri tabanında bulunan ilköğretim fen ve matematik alanları eğitimi anabilim dalı, ilköğretim matematik ĕgitimi anabilim dal, matematik eğitimi anabilim dal, ilköğretim matematik ögretmenliği anabilim dalı ve ilköğretim anabilim dalı detaylı aramasıla ulaşılan erişime açı 490 yüksek lisans tezi ve 112 doktora tezi olmak üzere toplam 602 lisansüstü tez oluşturmuştur. Araştırma, yapılan tezlerin bir meta-analitik incelemesi olması nedeniyle genel hatlarıla nitel bir çalışma olup tarama modelinde bir çalışmadır. Tezleri incelemek üzere araştırmacı tarafindan oluşturulup uzman görüşü alınan tez değerlendirme formu kullanılmıştır. Araştırma sonucunda kadın araştırmacıların son yıllarda daha fazla olduğu, yüksek lisans tezlerinde örneklem olarak en fazla ögrencilerin; doktora tezlerinde ise ögrenci ve ögretmen adaylarının kullanıldi ̆̆ çekmiştir. Öğrenme alanlarından en fazla geometri ve ölçme alanında çalışmaların yapıldı̆̆ fakat veri işleme alanında olan çalışmaların çok az olduğu görülmüşü̈r. Ayrıca eğitim araştırmalarında son yıllarda karma araştırmaların artması durumu bu tez çalışması kapsaminda da görülmüştür. $\underline{\text { Key Words }}$

Mathematics

education,

Mathematics

teaching,

Meta-Analytic,

Postgraduate thesis,

\begin{abstract}
This study was conducted with the aim of comparative investigation of master theses that were written in the field of Mathematics Education between the years of 2010-2017 in terms of the variables such as university, year, gender, language, research type, research model, sub-learning fields, data collection instruments, sampling and the statistical techniques that were applied. 490 postgraduate theses and 112 doctoral theses, total of 602 postgraduate theses, which were found in the database of Institute of Higher Education and accessible with the detailed search of department of primary science and mathematics education, department of primary education mathematics education, department of mathematics education, department of primary education mathematics teaching and department of primary education, constitute the sample of the research. As the study was a meta- analytic examination of the conducted thesis, it was basically a qualitative study in the descriptive model. The evaluation form which was developed by the researcher was used for examining the thesis. The results of the study point out that there are more female researchers in recent years; while the students are used as the sample of the study in the master thesis, both the students and the pre-service teachers are used in the PhD thesis. Geometry and Assessment are the sub fields that are conducted most while the studies in the data processing are seen to be very few. Besides, the increase in the mix research in educational research in the recent years is also observed in the context of the study.
\end{abstract}

Atıf için: $\quad$ Tereci, A., \& Bindak, R. (2019). 2010-2017 yılları arasında türkiye'de matematik eğitimi For Citation alanında yapılan lisansüstü tezlerin incelenmesi. Muğla Sıtkı Koçman Üniversitesi Ĕgitim Fakültesi Dergisi [MSKU Journal of Education], 6(1), 40-55. DOI: 10.21666/muefd.485737

\begin{tabular}{lll}
\hline Received: 20.11.2018 & Accepted: 25.03.2019 & Published: 01.05.2019
\end{tabular}

\footnotetext{
${ }^{1}$ Şehit Adem Yavuz Ortaokulu. e-posta: abdullah.tereci@ windowslive.com. ORCID: 0000-0002-2002-3184

${ }^{2}$ Gaziantep Üniversitesi Teknik Bilimler MYO. e-posta: recepbindak@yahoo.com. ORCID: 0000-0002-0005-7862
} 
Bireylere öğretilmesi gereken en önemli özelliklerden birisi bilimsel yöntem becerileridir (Ayaz ve Söylemez, 2015). Bilimsel yöntem becerilerinin öğretildiği kurum olan üniversiteler, bilimsel yöntemlerin en fazla kullanıldığı yer olmuştur. Bilim insanı yetiştirme ve ulusal bilim politikası için en önemli hususlardan biri lisansüstü eğitim olarak görülmektedir (Karaman ve Bakırc1, 2010). Bu nedenle toplumdaki insanların kendini geliştirme istekleri lisansüstü eğitime olan talebi arttırmıştır (Bozan, 2012). Lisansüstü eğitim ile yapılan bilimsel çalışmalar ile bilimsel yöntem becerileri geliştirilmeye çalışılmakta ve bu sayede alanyazın gün geçtikçe zenginleşmektedir.

Eğitim alanında yapılan lisansüstü çalışmalar, ülkenin eğitim sistemindeki sorunlarını ortaya koyma konusunda işlevsel hale gelmektedir. Bu nedenle lisansüstü çalışmaların akademik olarak bir bilimin ilerlemesindeki rolü büyüktür. Lisansüstü çalışmaların, var olan sorunları ortaya koyma ve bu sorunlara yönelik çözüm üretebilme bakımından önem teşkil ettiği düşünülmektedir. Bu durumlar göz önüne alındığında lisansüstü çalışmaların bir kısmı olan matematik eğitimi alanında yazılan yüksek lisans ve doktora tezleri önemli görülmektedir.

Özgün çalışmaların öneminin artmasıyla diğer çalışmalardan farklı olan araştırmalar bilim dünyasında saygın bir yerde tutulmaktadır. Yapılan bir araştırmanın özgün olması o çalışmanın niteliğinin artmasına katkı sağlamaktadır (Serin ve Turan, 2015). Bu nedenle yapılacak olan çalışmalar için alanyazın taramasının geniş ölçüde yapılmasının son derece önemli olduğu düşünülmektedir.

Son y1llarda matematik eğitimi üzerinde yapılan çalışmaların hangi yönde eğilimi olduğunu incelemek birçok kesimden bireye (öğrenci, öğretmen, öğretmen aday1, akademisyen vs.) sorgulama yapma olanağı tanıyacaktır (Çiltaş, Güler ve Sözbilir, 2012). Ayrıca alana yönelik çalışmaların incelenmesi o alandaki hangi konuların doygunluğa ulaştığını, ayrıca hangi yeni araştırmalara ihtiyaç olduğunu da ortaya koymaktadır (Karamustafaoğlu, 2009).

İlgili alanyazın incelendiğinde birçok alanda meta-analiz çalışması, meta-analitik çalışma, yapilan çalışmaların tematik ve metodolojik bakımdan incelenmesi gibi çalışmaların yapıldığ 1 görülmüştür. Lisansüstü tezlerin meta-analitik çalışmaya konu olduğu çalışmalar bulunmaktadır. Örneğin coğrafya eğitimi (Kaya, 2013); müzik eğitimi (Karkın, 2011); sınıf öğretmenliği (Şahin, Calp, Bulut, ve Kuşdemir, 2013); sosyal bilgiler eğitimi (Tarman, Acun ve Yüksel, 2010); okul öncesi eğitimi (Ahi ve Kıldan, 2013); üstün yetenekli öğrenciler (Özenç ve Özenç, 2013 ); karşılaştırmalı eğitim (IlımanPüsküllüoğlu ve Hoşgörür, 2017) matematik eğitimi (Yücedağ, 2010) gibi alanlarda yapılan yüksek lisans tezleri üzerine meta-analitik çalışmalar yapıldığı görülmektedir. Bunun dışında matematik eğitimi ile ilişkili (başarı-tutum, yapılandırmacı yaklaşım, eğilimler, öğrenme yaklaşımları vb) bazı konuların ele alındığı meta-analitik çalışmalar da bulunmaktadır (Ayaz ve Şekerci, 2015; Baki, Güven, Karataş, Akkan ve Çakıroğlu, 2011; Çelik, 2013; Göktaş, Küçük, Aydemir, Telli, Arpacık, Yıldırım ve Reisoğlu, 2012; İlhan, 2011; Kaşarc1, 2013; Küçük ve Aycan, 2014; Ulutaş ve Ubuz, 2008).

İlgili alanyazın incelendiğinde birçok alanda tez ve akademik çalışmaların meta-analiz çalışması yapıldığ 1 görülmüştür. 2010 yılına kadar matematik eğitimi araştırmalarının incelenmesi yeni yapılacak olan çalışmalara 1şık tutmuştur. 2010 yılından itibaren yapılan çalışmaların incelenmemesi, eğitim politikasının değişimi, eğitim sistemine yeni öğrenci ve öğretmenlerin katılması, ilgili çalışmaların artması gibi nedenler yeni bir meta-analitik çalışmayı gerekli kıldığı düşünülmektedir. Bu araştırmadan elde edilecek sonuçların Türkiye'de son on yılda matematik eğitimi alanında yapılan lisansüstü tez çalışmalarının bir resmini ortaya çıkarması beklenmektedir. Dolayısıyla alanyazına katkı sağlayacağı ve matematik eğitimi araştırmacılarına yol göstereceği düşünülmektedir.

İlgili alanyazın incelendiğinde birçok alanda yapılan araştırmalara yönelik meta analiz/analitik çalışmaların mevcut olduğu görülmüsstür. Son yıllarda matematik eğitimi alanında Yücedağ (2010) çalışmasında 2000-2009 yılları arasında matematik eğitimi alanında yapılan çalışmaları incelemiştir. Bu çalışmada 390 lisansüstü tezi ve bazı dergilerde yayınlanan 153 makale incelenmiştir. Araştırmanın sonuçlarına göre lisansüstü tezlerde öğretim yöntemi, makalelerde ise duyuşsal alan konularında yığılma olduğu görülmüştür. Ayrıca lisansüstü tezlerde geometri ve cebir, makalelerde ise daha çok cebir öğrenme alanları üzerinde çalışmaların yoğunlukta olduğu araştırmanın bir başka dikkat çeken sonucu olmuştur. 
Matematik eğitimi alanında yapılan çalışmaları inceleyen başka bir yüksek lisans tez çalışmasında İlhan (2011) matematik eğitimi alanında 2005-2009 yılları arası yayınlanmış olan lisansüstü tezler ile ulusal ve uluslararası makaleler incelemiştir. Araştırma bulgularına göre uluslararası araştırmalarda bilişsel alana yönelim görülürken ulusal araştırmalarda öğretim yöntemi ve başarı gibi konular üzerinde durulmuştur. Ayrıca ulusal araştırmalarda deneysel araştırmaların yoğunlukta olduğu dikkat çeken başka bir bulgu olmuştur.

Genel olarak matematik eğitimi araştırmalarını inceleyen araştırmaların yanı sıra Nacar (2015)'ın 2005-2014 yılları arasında üstün yeteneklilerin matematik eğitimi üzerine yapılan çalışmaları inceleyen yüksek lisans tezi de bulunmaktadır. Ayrıca Ilıman-Püsküllüoğlu ve Hoşgörür (2017) tarafından yapılan çalışmada karşılaştırmalı eğitim alanında yapılmış lisansüstü tezler incelenmiştir. Lisansüstü tezlerin yanı sıra eğitim dergilerinde yayınlanan matematik eğitimi alanında yapılan çalışmaları inceleyen Ulutaş ve Ubuz (2008)'un çalışmaları da bulunmaktadır. Bu araştırma 2008 yılında 2000-2006 yılları arasında bazı eğitim dergilerinde yayınlanan matematik eğitimi araştırmalarının incelendiği bir araştırmadır. Bu araştırmada 4 farklı dergide yayınlanan 129 makale çalışma dili, araştırma çeşidi, örneklem, araştırma başlıkları, konu başlıkları, kullanılan yöntem, yazar kurumları ve veri toplama yöntemleri bazında incelenmiş ve analiz edilmiştir. Elde edilen bulgulara göre araştırma çeşidi olarak en fazla deneysel araştırmalar, örneklem olarak en fazla ilköğretim öğrencileri ve öğretmen adayları, araştırma başlığı altında bilişsel, duyuşsal ve öğretim yöntemleri konularında, veri toplama bazında ise en fazla anket ve test kullanılmıştır. Bunlara ek olarak ise matematik konularında en fazla sayılar ve geometri konularının seçilmesi dikkat çekmiştir.

$\mathrm{Bu}$ çalışmaların yanında Baki vd., (2011) 1998-2007 yılları arasında matematik eğitimi araştırmalarındaki eğilimleri incelemişlerdir. Toplam 284 lisansüstü tezin incelendiği çalışmanın sonuçlarına göre araştırma tasarımı olarak en fazla deneysel tasarımın, örneklem olarak en fazla öğrencilerin, veri toplama aracı olarak en fazla anket ve başarı testinin kullanıldığı belirlenmiştir. Bunların yanı sıra araştırma başlığı olarak öğretmen müdahale yöntemleri en fazla çalışılan konu olurken, matematiğin öğreniminde teknoloji kullanımı başlığı en az çalışılan konu başlığı olduğu, nicel yöntemlerin kullanılma oranının \%45.1 olduğu rapor edilmiş̧ir.

Meta-analitik çalışmalar belirli bir alanda ya da konuda yapılan araştırmaları bir araya getirerek bu çalışmalardan bir takım sonuçlara ulaşmayı hedefler ve bireysel çalışmaların sınırlılıklarını azaltır (Büyüköztürk, Çakmak, Akgün, Karadeniz ve Demirel, 2010). Bu araştırmada, 2010 yılından itibaren matematik eğitimi alanında yapılan lisansüstü tezler tematik, metodolojik ve kullanılan istatistiksel yöntemlere göre incelenmiş ve bir takım karşılaştırmalı sonuçlara ulaşılmıştır.

Gerek yeni açılan üniversitelerde gerek diğer üniversitelerde son yıllarda yapılan matematik eğitimi alanındaki lisansüstü tezlerin tematik yönden incelenmesi ve elde edilen bulguların rapor edilmesi alanyazındaki boşluğu dolduracağı düşünülmektedir. Bu nedenle yapılan bu araştırma ile son yıllarda matematik eğitimi alanında yapılan tezlerin genel bir resmi ortaya konulacaktır.

$\mathrm{Bu}$ araştırma ilgili alanda yazılmış tezlerin bazı değişkenlere yönelik incelenmesi ve son yıllarda matematik eğitimi alanında yazılmış lisansüstü tezlerin genel bir resmini ortaya koymak amacıyla yapılmıştır. Bu nedenle bu araştırmanın, alanda yapılacak olan yeni araştırmalarda araştırmacılara yol gösterici olması beklendiğinden önemli görülmektedir.

İlgili alanyazında matematik eğitimi alanında yapılan meta analitik çalışmalar yapılacak olan yeni çalışmalara 1 şık tutmuş ve yeni çalışma alanlarını ortaya koymuştur. Bu çalışmada da 2010-2017 yılları arasında matematik eğitimi alanında yapılan yüksek lisans ve doktora tezlerinin metodolojik ve tematik yönden incelenmesi ve yapılacak olan yeni çalışmalara yol gösterici olması amacıyla yapılmıştır. Bu amaç doğrultusunda aşağıdaki araştırma sorularına yanıt aranmıştır.

2010-2017 yılları arasında matematik eğitimi alanında yapılan lisansüstü tezler;

1-Yıllara göre nasıl bir dağılım göstermektedir?

2-Öğrenme alanı ve sayı bakımından üniversitelere göre nasıl bir dağılım göstermektedir?

3-Yazar cinsiyetine göre nasıl bir dağılım göstermektedir? 
4-Araştırma yaklaşımı bakımından nasıl bir dağılım göstermektedir?

5-İnceleme alanı bakımından nasıl bir dağılım göstermektedir?

6-Kullanılan örneklem gruplarına göre nasıl bir dağılım göstermektedir?

7-Kullanılan veri toplama araçlarına göre nasıl bir dağılım göstermektedir?

8-İstatistiki yöntemlere göre nasıl bir dağılım göstermektedir?

9-Öğrenme alanı bakımından nasıl bir dağılım göstermektedir?

10-Öğrenme alanı ile araştırma yaklaşımı arasında anlamlı bir dağılım var mıdır?

11-Öğrenme alanı ile araştırma türü arasında anlamlı bir dağılım var mıdır?

12-Tezin yapıldığı üniversiteye göre öğrenme alanları nasıl bir dağılım göstermektedir?

13-Yıllara göre öğrenme alanları nasıl bir değişiklik göstermektedir?

\section{Yöntem}

Nitel araştırma yaklaşımının içinde meta-analiz yöntemi belirli bir konu üzerinde yapılan çalışmaların sonuçlarını bir araya getirerek güvenilir sonuçlar elde etmeyi amaçlar (Çarkungöz ve Ediz, 2009). Meta-analiz çalışmaları benzer konulardaki çalışmaların bulgularını birleştirilip özgün bulgulara ulaşmak için kullanılan istatistiki bir tekniktir (Crombieve \& Davies, 2009). Meta-analitik çalışmalar ise analizlerin analizi olarak bilinmektedir (Batdı, 2014). Bu çalışmada matematik eğitimi alanında 2010-2017 yılları arasında matematik eğitiminde Türkiye'de yapılan çalışmaların inceleme alanı, alt öğrenme alanı ve örneklem bakımından nasıl bir eğilimde olduğunu incelenmiş̧tir. Yapılan çalışmaların analiz sonuçları incelenmiş ve Türkiye' deki matematik eğitimi çalışmalarının inceleme alanı, öğrenme alanı ve çalışılan örneklem bakımından nasıl bir eğilimde olduğu ortaya koymak için meta-analitik çalışma yapılmıştır.

$\mathrm{Bu}$ çalışma nitel bir yaklaşımla yapılmış genel tarama modelindedir. Var olan çalışmaların sonuçları ile sayısal olarak işlem yapılmadığından dolayı bu çalışma meta-analizden ziyade bir meta-analitik çalışmadır.

\section{Evren ve Örneklem}

Araştırmanın evrenini YÖK ulusal tez merkezindeki matematik eğitimi alanında yapılmış lisansüstü tezler oluşturmaktadır. Buna göre çalışmanın evreni, ulusal tez merkezinde "İlköğretim fen ve matematik alanları eğitimi anabilim dalı", "İlköğretim matematik eğitimi anabilim dalı", "Matematik eğitimi anabilim /bilim dalı", "İlköğretim matematik öğretmenliği anabilim dalı", "İlköğretim matematik öğretmenliği bilim dalı", "İlköğretim anabilim dalı" ve "Matematik öğretmenliği bilim dalı" anabilim/ bilim dallarında kayıtlı tezlerdir. Araştırmanın örneklemi ise sayılan bilim dalı ve anabilim dallarında erişime açı 490 yüksek lisans tezi ve 112 doktora tezi olmak üzere toplam 602 lisansüstü tezinden oluşmaktadır. Bu araştırmada, araştırmanın amacına bağlı olarak bilgi açısından zengin olan durumları detaylı olarak inceleme olanağı (Öztürk vd., 2010) verdiğinden dolayı amaçsal örnekleme kullanılmıştır. Örneklem seçiminde matematik anabilim dalı ve bilim dallarında erişime açık olan lisansüstü tezleri ölçüt olarak alınmıştır.

\section{Verilerin Toplanması}

Araştırmanın verileri belgesel tarama tekniği ile toplanmıştır. Belgesel tarama genel tarama ve içerik çözümlemesi şeklinde iki farklı şekilde yapılabilir. İçerik çözümlemesi, belirli araştırmaların belirli özelliklerini sayısallaştırarak belirleme amacı ile yapılır (Kıncal, 2014). Bu nedenle bu çalışmanın verilerini toplarken içerik çözümlemesi yöntemi kullanılmıştır.

Çalışmada veri toplama aracı olarak araştırmacılar tarafından geliştirilen tez inceleme formu kullanılmıştır. Tez inceleme forumunu oluştururken farklı alanlarda yapılmış meta-analiz/metaanalitik çalışmalar incelenmiş ve kriterler belirlenmiştir. Taslak form oluşturulduktan sonra uzman görüşü alınmış gerekli düzeltmeler yapıldıktan sonra pilot uygulamaya geçilmiştir. Pilot uygulama sonunda araştırma için yeni ve önemli bilgiler vermeyecek ölçütler formdan çıkarılmış ve tekrar uzman görüşüne başvurulmuştur. Matematik eğitimi alanında doktora yapmış/yapan 5 kişi ve Ölçme Değerlendirme alanında yüksek lisans/doktora yapmış/yapan 4 kişi ile birlikte kodlar oluşturulmuş 
uzman desteği ile birlikte kategoriler belirlenmiştir. Örnekleme alınan her tez için tez inceleme formu oluşturulmuş ve bu bilgiler Microsoft Excel programına aktarılmıştır.

\section{Verilerin Analizi}

Örnekleme giren tezlerden veriler belgesel tarama tekniği ile toplanmıştır. Bu amaçla her bir tez için tez inceleme formu kullanılmıştır. Araştırmada ele alınan değişkenlerin tümü kategorik olup aşağıda kısaca açıklanmıştır.

Tezin yapıldığı üniversite, tez türü (yüksek lisans-doktora), araştırmacı cinsiyeti, tezin yazıldığı yıl, tez yazımında kullanılan dil, tezin üzerinde çalıştığı öğrenme alanı (sayılar ve işlemler, cebir, geometri ve ölçme, veri işleme, olasılık), tezin üzerinde yazıldığı inceleme alanı (bilişsel alan, duyuşsal alan, bir konuya yönelik inceleme), araştırma yaklaşımı (nitel, nicel, karma), tezin araştırma türü (betimsel, ilişkisel, müdahaleli), tezin örneklemi (öğrenci, öğretmen, öğretmen adayı, veli, karma vb.), veri toplama araçları (gözlem, görüşme, anket, ölçek, başarı testleri, dokuman vb.) ve araştırmada kullanılan istatistiki yöntemler olarak belirlenmiştir.

Araştırma verileri SPSS programında analiz edilmiştir. Verilerin analizi sürecinde frekans, yüzde gibi betimsel istatistikler yapılmış ve yorumlanmıştır. Ayrıca kategorik iki değişken arasındaki ilişkiyi ortaya çıkarmak için Ki-kare bağımsızlık testi uygulanmıştır. Ki-kare bağımsızlık testinde " $\mathrm{H}_{0}$ : İki değişkenler birbirinden bağımsızdır" sıfır hipotezi test edilmiştir. İstatistiksel anlamlılık düzeyi 0.05 olarak kabul edilmiştir.

\section{Geçerlik ve Güvenirlik}

Güvenirliği sağlamak amacıyla araştırma yapılırken duyarlılık, tutarlılık ve tekrar edilebilirlik nitelikleri (Karaca, Yurdabakan, Çetin, Nartgün, Bıçak ve Gömleksiz, 2010) üzerinde önemle durulmuştur. Araştırmanın tutarlılığını test etmek amacıyla araştırmacının yanı sıra ölçme değerlendirme alanında yüksek lisansını tamamlamış bir kişi, matematik eğitiminde yüksek lisansını tamamlamış ve doktoraya devam eden iki kişi, üç matematik öğretmeni ve iki Türkçe öğretmeninden oluşan sekiz kişilik gruba incelenen tezlerden rastgele 20 tanesi verilmiş ve belirlenen kriterlere göre tezlerin incelenmesi istenmiştir. Sekiz kişi 20 lisansüstü tezi içerisinde yedi kategori bulunan tez inceleme formuna göre incelemiştir. Sonuç olarak 20 tez için her maddeyi baz alan 1120 değerlendirme sonucu ortaya çıkmıştır. Değerlendirme yapılırken y1l, üniversite adı, cinsiyet ve dil kategorileri üzerinde durulmamış olup değerlendirmeye tez türü, inceleme alanı, öğrenme alanı, veri toplama aracı, örneklem, araştırma yaklaşımı ve kullanılan istatistiki yöntemler kategorileri alınmıştır. 7 kategori için 20 kişinin vermiş olduğu cevaplara yönelik frekanslar tablolaştırılmış toplamda 1120 değerlendirme sonucunun araştırmacının tez değerlendirmeleri karşılaştırıldığında 987 sonucun araştırmacının sonucuyla uyuştuğu 133 sonucun araştırmacının değerlendirmesine göre eksik ya da farklı olduğu görülmüştür. Ortaya çıkan sonuçlara göre \%88.13'lük bir uyuşma olduğu görülmüştür. Böylece araştırmanın güvenirlik anlamında tutarlılı̆̆ test edilmiştir.

\section{Bulgular}

\section{1-Matematik eğitimi alanında yapılmış lisansüstü tezler sayı bakımından yıllara göre nasıl bir dağılım göstermektedir?}

Araştırmanın örneklemini 2010-2017 yılları arasında YÖK ulusal tez merkezi Matematik Eğitimi Bilim Dalı'nda erişime açık olan yüksek lisans ve doktora tezleri oluşturmuş̧tur. Tablo l'de yıllara göre tez sayıları sunulmuştur. Tablo 1'e göre en fazla lisansüstü tez 2013 yılında (128 tez), en az lisansüstü tez ise 2016 yılında (57 tez) yapılmıştır.

Şekil 1'de görüldüğü üzere yüksek lisans tezleri sayısı 2013 yılında, doktora tezleri sayısı ise 2013 yılında en yüksek değerine ulaşmıştır. Yüksek lisans tezlerinin yıllara göre sayısı doktora tezlerinin sayısına göre daha büyük dalgalanma göstermektedir. 
Tablo 1. 2010-2017 Yılları Arası Lisansüstü Tez Sayıları

\begin{tabular}{|c|c|c|c|c|}
\hline Y1l & $\begin{array}{c}\text { Yüksek } \\
\text { Lisans }\end{array}$ & Doktora & $\begin{array}{c}\text { Tüm tezler içinde } \\
\text { Doktora oran }\end{array}$ & Toplam \\
\hline 2010 & 76 & 14 & $\% 15.6$ & 90 \\
\hline 2011 & 72 & 11 & $\% 13.2$ & 83 \\
\hline 2012 & 80 & 20 & $\% 20.0$ & 100 \\
\hline 2013 & 107 & 21 & $\% 16.4$ & 73 \\
\hline 2014 & 56 & 17 & $\% 23.3$ & 71 \\
\hline 2015 & 52 & 19 & $\% 17.5$ & 57 \\
\hline 2016 & 47 & 10 & $\% 18.6$ & 602 \\
\hline Toplam & 490 & 112 & &
\end{tabular}

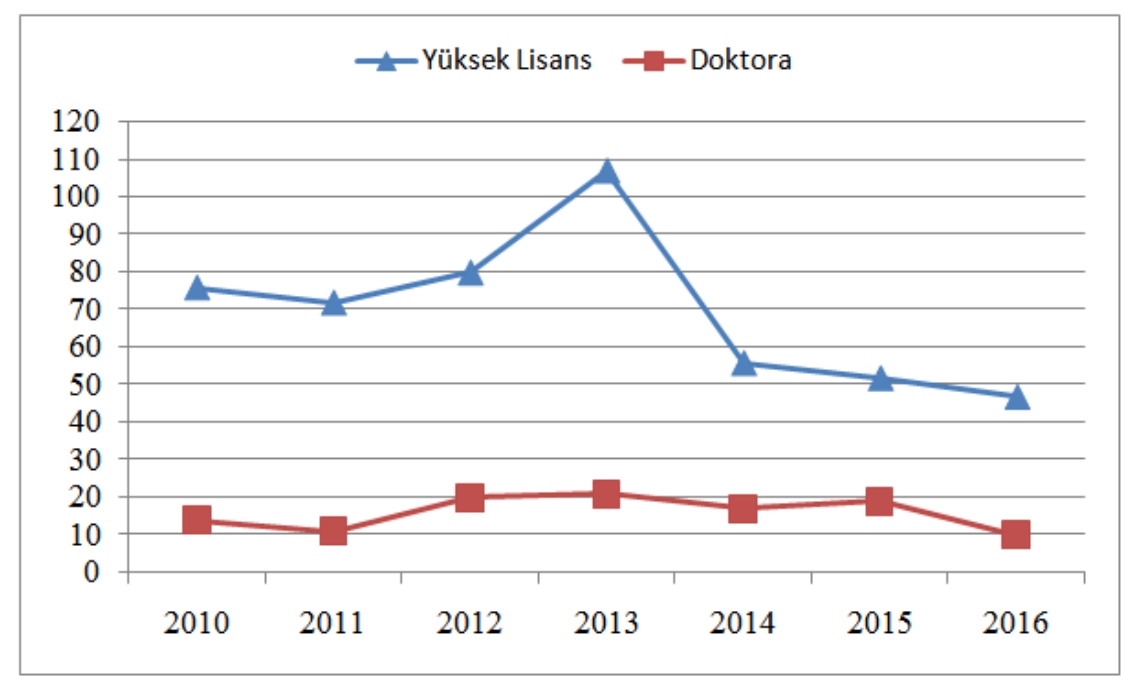

Şekil 1. 2010-2017 Yılları Arası Yapılan Lisansüstü Tezlerin Sayısı

\section{2- Üniversitelere göre matematik eğitimi alanında yapılmış lisansüstü tez sayıları nasıl bir dağılım göstermektedir?}

Matematik eğitimi alanında lisansüstü eğitim veren üniversiteler bünyesinde yapılan lisansüstü tezlere yönelik bilgiler Tablo 2'de sunulmuştur.

Tablo 2. Lisansüstü Tezlerin Yapıldığg Üniversitelere Göre Sayıları(En Yüksek İlk 10)

\begin{tabular}{lccc}
\hline Üniversite Adı & Yüksek Lisans & Doktora & Toplam \\
\hline Gazi Üniversitesi & 62 & 18 & 80 \\
Marmara Üniversitesi & 51 & 12 & 63 \\
Karadeniz Teknik Üniversitesi & 26 & 30 & 56 \\
Atatürk Üniversitesi & 34 & 18 & 52 \\
Dokuz Eylül Üniversitesi & 35 & 16 & 51 \\
Gaziantep Üniversitesi & 30 & 0 & 30 \\
Necmettin Erbakan Üniversitesi & 27 & 1 & 28 \\
Orta Doğu Teknik Üniversitesi & 24 & 4 & 28 \\
Balıkesir Üniversitesi & 17 & 5 & 22 \\
Osmangazi Üniversitesi & 22 & 0 & 22 \\
\hline Tüm üniversiteler & 490 & 112 & 602 \\
\hline
\end{tabular}

En fazla lisansüstü tez Gazi Üniversitesi bünyesinde (62 yüksek lisans ve 18 doktora olmak üzere toplam 80) yapılmıştır. Gazi Üniversitesi'ni 51 yüksek lisans ve 12 doktora tezi olmak üzere toplam 63 lisansüstü tez ile Marmara Üniversitesi izlemektedir. 
3-Lisansüstü tezler yazar cinsiyetine göre nasıl bir dağılım göstermektedir? İncelenen tezlerin yazar cinsiyeti bakımından bulguları Tablo 3 te gösterilmiştir.

Tablo 3. Yazar Cinsiyeti Bakımından Lisansüstü Tez Sayılarının Dağılımı (a)

\begin{tabular}{lccc}
\hline Cinsiyet & Yüksek Lisans & Doktora & Toplam \\
\hline Erkek & $172(\% 35.1)$ & $56(\% 50)$ & 228 \\
Kadın & $318(\% 64.8)$ & $56(\% 50)$ & 374 \\
\hline
\end{tabular}

(a): sütun yüzdesi alınmıştır. $\quad \chi^{2}=8.5929 ;$ s.d. $=1 \mathrm{p}=.003$

Tablo 3'de görüldüğü üzere kadın araştırmacıların matematik eğitimi alanında daha fazla lisansüstü tez yazdıkları görülmektedir. Ki-kare bağımsızlık testi sonuçlarına göre cinsiyet ile tez türü arasındaki ilişki anlamlıdır ( $\mathrm{p}<.05)$. Toplam 602 lisansüstü tezin 374'ü kadın araştırmacılar tarafından, 228'i ise erkek araştırmacılar tarafından yapılmıştır. Ek olarak doktora tezlerinde erkek ve kadın araştırmacıların sayılarının eşit olması dikkat çeken bir durum olmuştur.

4-Lisansüstü tezler araştırma yaklaşımı bakımından nasıl bir dağılım göstermektedir? Araştırma yaklaşımları nitel, nicel ve karma olarak sınıflandırılır. Bu sınıflandırmaya uygun olarak incelenen tezler kategorize edilmiştir. Elde edilen bulgular Tablo 4 'te gösterilmiştir.

Tablo 4. Araştırma Yaklaşımı Bakımından Lisansüstü Tezlerin Sayıları

\begin{tabular}{|c|c|c|c|}
\hline Araştırma Yaklaşımı & Yüksek Lisans & Doktora & Toplam \\
\hline Nitel & 185 & 43 & 228 \\
\hline Nicel & 176 & 18 & 194 \\
\hline Karma & 129 & 51 & 180 \\
\hline
\end{tabular}

Bulgulara göre nitel araştırmalar (\%37.9) çoğunluktadır. Yüksek lisans tezlerinde karma yaklaşımın daha az kullanılmasına rağmen doktora tezlerinde karma yaklaşımın daha çok kullanılması dikkat çekmiştir. Ayrıca yapılan ki-kare testine göre araştırma yaklaşımı ile tez türü arasında anlamlı ilişki olduğu belirlenmiştir $(\mathrm{p}<.05)$.

\section{5-Lisansüstü tezler inceleme alanı bakımından nasıl bir dağılım göstermektedir?}

$\mathrm{Bu}$ araştırmada lisansüstü tezlerin inceleme alanı olarak "bilişsel alan, duyuşsal alan, bir konuya yönelik inceleme, hem bilişsel hem duyuşsal alan" kategorilerine yer verilmiştir. İncelenen tezler inceleme alanı olarak bu kategoriler halinde sınıflandırılmış olup bu sınıflamaya ait bulgular Tablo 5 'te gösterilmiştir. Öğrencilerin, öğretmenlerin vb. bir kavram ya da konu hakkındaki bilgileri, yapmış oldukları hatalar gibi bilişsel boyuttaki çalışmalar bilişsel alan, tutum, algı, inanç gibi boyutlar duyuşsal alan, dokuman incelemesi, pür matematik gibi çalışmalar ise bir konuya ait inceleme olarak kategorize edilmiştir.

Tablo 5. İnceleme Alanı Bakımından Lisansüstü Tezlerinin Sayısı

\begin{tabular}{lccc}
\hline \multicolumn{1}{c}{ İnceleme Alanı } & Yüksek Lisans & Doktora & Toplam \\
\hline Bilişsel alan & 319 & 76 & 395 \\
Duyuşsal alan & 61 & 7 & 68 \\
Bir Konuya Yönelik İnceleme & 46 & 12 & 58 \\
Hem Duyuşsal Hem Bilişsel Alan & 64 & 17 & 81 \\
\hline
\end{tabular}

İnceleme alanı bakımından yüksek lisans tezlerinde bilişsel alan üzerinde yoğunlaşıldığı, doktora tezlerinde ise duyuşsal alana yönelik ilginin az olduğu dikkat çekmektedir. Ki-kare bağımsızlık testi sonucuna göre inceleme alanı ile tez türü arasında 0.05 düzeyinde anlamlı ilişki bulunmamaktadır $(\mathrm{p}>.05)$. 


\section{6-Tezler, kullanılan örneklem gruplarına göre nasıl bir dağılım göstermektedir?}

Araştırma sürecinde incelenen tezler, örneklem gruplarına göre 6 kategoriye ayrılmıştır. Bu kategoriler öğrenci, öğretmen, öğretmen adayı, yönetici, veli ve doküman şeklindedir. İncelenen tezler, üzerinde çalışılan örneklem grubuna göre kategorilere ayrıldığında bazı tezlerin birden fazla kategoriye girdiği görülmüştür. Bu ise beklenen bir durumdur, zira bir tezin örneklemi, öğrenci / öğretmen, yönetici / veli, öğretmen gibi birden fazla gruptan oluşabilmektedir. Lisansüstü tezlerde üzerinde çalış1lan örneklem grubu sıklıklarının tez türüne (yüksek lisans veya doktora) göre dağılımlarının istatistiksel olarak anlamlı olup olmadığını belirlemek amacıyla Ki-kare uygunluk testi uygulanmış ve sonuçlar Tablo 6'da sunulmuştur.

Tablo 6. Lisansüstü Tezler İle Kullanılan Örneklem Arasındaki İlişki

\begin{tabular}{lcccc}
\hline Örneklem Grubu & $\begin{array}{c}\text { Yüksek Lisans } \\
(\mathrm{n}=490)\end{array}$ & $\begin{array}{c}\text { Doktora } \\
(\mathrm{n}=112)\end{array}$ & $\begin{array}{c}\chi^{2} \\
(\mathrm{sd}=1)\end{array}$ & $\mathrm{p}$ \\
\hline Öğrenci & $\% 59.1$ & $\% 47.3$ & 5.203 & $.023 *$ \\
Öğretmen & $\% 17.1$ & $\% 19.6$ & 0.416 & .519 \\
Öğretmen Aday1 & $\% 19.7$ & $\% 39.3$ & 19.526 & $.000^{*}$ \\
Yönetici & $\% 0$ & $\% 0$ & - & - \\
Veli & $\% 0.2$ & $\% 0$ & 0.228 & .633 \\
Döküman & $\% 10.4$ & $\% 4.5$ & 3.777 & .052 \\
\hline
\end{tabular}

\footnotetext{
$* \mathrm{p}<.05$
}

Tablo 6'ya göre yüksek lisans tezlerin örneklem olarak \%59.1'inde öğrenci, \%17.1'inde öğretmen, \%19.7'sinde ögretmen aday1, \%0.2'sinde veli \%10.4'ünde ise dokuman kullanılmıştır. Doktora tezlerinin ise \%47.3'ünde öğrenciler, \%19.6'sında öğretmenler, \%39.3'ünde öğretmen adayları, $\% 4.5$ 'inde dokumanlar örneklem olarak kullanılmıştır. Örneklem olarak yüksek lisans ve doktora tezlerinde yöneticiler, doktora tezlerinde ise veliler kullanılmamıştır. Öte yandan kullanılan örneklem grubu ile tez türü (YL/Dok.) arasında bazı anlamlı dağılımlar olduğu söylenebilir. Örneklemin öğrenci olduğu tez sayısı frekans bakımından yüksek lisans ile doktora tezleri arasında anlamlı bir dağılım vardır $(\mathrm{p}<.05)$. Doktora tezlerinin \%39.3'ünde örneklem olarak öğretmen adayı kullanılmış olup dağılım anlamlıdır. Bunlara ek olarak örneklemin öğretmen ve veli olduğu tez sayılarının frekans bakımından yüksek lisans ve doktora tezleri arasında anlamlı bir dağılım olmadığı söylenebilir $(\mathrm{p}>.05)$.

\section{7-Tezler, kullanılan veri toplama araçlarına göre nasıl bir dağılım göstermektedir?}

Araştırma sürecinde incelenen tezlerin kullanmış olduğu veri toplama araçları gözlem, görüşme formu, başarı testleri, tutum-alg1-kişilik-yetenek testleri, anket-ölçek ve dokuman olmak üzere kategorilere ayrılmış ve veri girişi sağlanmıştır. Tez türü (yüksek lisans-doktora) ile kullanılan veri toplama araçları arasında anlamlı bir ilişkinin olup olmamasına yönelik elde edilen bulgular Tablo 7'de sunulmuştur. Bir tez çalışmasında birden fazla veri toplama aracı kullanılabildiğinden Ki-kare uygunluk testi her bir satıra uygulanmıştır. Tabloda frekans yerine tez türüne göre kullanılan veri toplama aracı türü yüzdelerine yer verilmiştir.

Tablo 7. Lisansüstü Tezler İle Kullanılan Veri Toplama Aracı Arasındaki İlişki

\begin{tabular}{lcccc}
\hline Veri Toplama Aracı & $\begin{array}{c}\text { YL } \\
(\mathrm{n}=490)\end{array}$ & $\begin{array}{c}\text { Doktora } \\
(\mathrm{n}=112)\end{array}$ & $\begin{array}{c}\chi^{2} \\
(\mathrm{sd}=1)\end{array}$ & $\mathrm{p}$ \\
\hline Gözlem & $\% 11.8$ & $\% 44.6$ & 67.065 & $.000^{*}$ \\
Görüşme Formu & $\% 39.8$ & $\% 70.5$ & 34.667 & $.000^{*}$ \\
Başarı Testleri & $\% 50.0$ & $\% 53.6$ & 0.466 & .495 \\
Tutum-Algi-Kişilik-Yetenek Testleri & $\% 28.9$ & $\% 33.9$ & 1.120 & .290 \\
Anket-Ölçek & $\% 19.5$ & $\% 18.8$ & 0.034 & .854 \\
Dokuman & $\% 25.8$ & $\% 42.0$ & 11.604 & $.001^{*}$ \\
\hline
\end{tabular}

$* \mathrm{p}<.05$

Tablo 7'den yüksek lisans tezlerinin yarısında başarı testlerinin kullanılmış olduğu, buna karşıllık gözlemin en az (\%11.8) kullanılan veri toplama şekli olduğu görülmektedir. İncelenen doktora tezlerinin büyük çoğunluğu (\%70.5) veri toplamada görüşme formu kullanmışken \%18.8'inin anketölçek kullandığı belirlenmiştir. Ki-kare testi sonuçlarına göre, gözlem yoluyla veri toplamanın daha 
çok doktora tezlerinde olduğu görülmektedir $(\mathrm{p}<.05)$. Ayrıca bu durum görüşme formu ve dokuman için de geçerlidir. Dolayısıyla veri toplama araçlarının gözlem, görüşme ve dokuman olduğu tez sayısı frekans bakımından yüksek lisans ile doktora tezleri arasında anlamlı bir fark vardır ve bu veri toplama araçları doktora tezlerinde daha çok kullanılmaktadır. Tutum-algi-kişilik-yetenek testleri ve anketler doktora tezlerinde daha çok kullanılmış olarak görünse de bu dağılım anlamlı değildir ( $\mathrm{p}>.05)$.

\section{8-Tezler, kullanılan istatistiksel yöntemlere göre nasıl bir dağılım göstermektedir?}

Lisansüstü tezlerde kullanılan istatistiksel teknikler sınıflandırılırken 9 farklı kategori altında veri girişleri sağlanmıştır. Pür matematik olarak herhangi matematik konusu üzerinde derinlemesine inceleme yapılan tezlerde istatistiksel teknik kullanılmadığ 1 için bu tür tezler "istatistiksel teknik yok" olarak sınıflandırılmıştır. Diğer tezler ise betimsel analiz, t-test, varyans analizi, nonparametrik testler, regresyon-korelasyon, faktör analizi, ki-kare, içerik analizi ve kod oluşturma başlıkları altında sınıflandırılmıştır. Örneklem ve veri toplama araçları kısmında belirtildiği üzere bir tezde birden fazla istatistiksel teknik kullanılabildiğinden tez frekanslarının dağılımına her bir teknik için ayrı ayrı (satır boyunca) bakılmıştır. Anlamlı dağılım olup olmadığını belirlemek için Ki-kare uygunluk testi uygulanmış, Tablo 8'de tezin yüksek lisans veya doktora olmasına göre her bir tekniğin kullanılma sıklığ yüzde olarak verilmiştir.

Tablo 8. Lisansüstü Tezler İle Kullanılan İstatistiksel Teknikler Arasındaki İlişki

\begin{tabular}{lcccc}
\hline İstatistiksel Teknik & $\begin{array}{c}\text { YL } \\
(\mathrm{n}=490)\end{array}$ & $\begin{array}{c}\text { Doktora } \\
(\mathrm{n}=112)\end{array}$ & $\begin{array}{c}\chi^{2} \\
(\mathrm{sd}=1)\end{array}$ & $\mathrm{p}$ \\
\hline İstatistiksel Teknik Yok & $\% 7.3$ & $\% 2.7$ & 3.250 & .071 \\
Betimsel İstatistik & $\% 49.4$ & $\% 59.8$ & 3.974 & $.046^{*}$ \\
T-test & $\% 31.7$ & $\% 31.3$ & 0.009 & .925 \\
Varyans Analizi & $\% 17.3$ & $\% 17.0$ & 0.006 & .937 \\
Nonparametrik Testler & $\% 14.2$ & $\% 25.0$ & 7.789 & $.005^{*}$ \\
Regresyon-Korelasyon & $\% 16.9$ & $\% 14.3$ & 0.445 & .505 \\
Faktör Analizi & $\% 3.7$ & $\% 3.6$ & 0.002 & .965 \\
Ki-kare & $\% 3.0$ & $\% 3.6$ & 0.082 & .775 \\
İçerik Analizi & $\% 23.0$ & $\% 42.9$ & 18.461 & $.000^{*}$ \\
Kod Oluşturma & $\% 21.1$ & $\% 25.9$ & 1.201 & .273 \\
\hline
\end{tabular}

$* \mathrm{p}<.05$

Tablo 8'e göre yüksek lisans tezlerinin \%7.3'ünde istatistiksel teknik kullanılmamış olup, betimsel istatistik (frekans, yüzde) \%49.4 oranla en fazla kullanılan istatistiksel teknik olmuştur. Yüksek lisans tezlerinde en az kullanılan istatistiksel teknik ise \%3 oranıyla ki-kare testi olduğu görülmektedir.

Doktora tezlerine bakılacak olursa doktora tezlerinde \%42.9 oranıyla içerik analizi en fazla kullanılan teknik olmuştur. Doktora tezlerinde ki-kare (\%3.6) ve faktör analizi (\%3.6)'nin çok az kullanıldığ dikkat çekmektedir.

Yüksek lisans ve doktora tezleri karşıllaştırıldığında kullanılan istatistiksel teknikler arasında betimsel analiz, içerik analizi ve parametrik olmayan test kullanımı bakımından anlamlı bir fark olduğu görülmektedir. Yüksek lisans tezlerinin \%49.4'ünde, doktora tezlerinin \%59.8'inde betimsel analiz kullanılmıştır. Hesaplanan Ki-kare testine göre $\mathrm{p}<.05$ olduğundan bu dağılım anlamlıdır. Dolayısıyla doktora tezlerinde yüksek lisans tezlerine göre daha çok betimsel analiz yapılmakta olduğu söylenilebilir. Yüksek lisans tezlerinin \%23'ünde, doktora tezlerinin \%42.9'unda içerik analizi kullanılmıştır. Hesaplanan Ki-kare testine göre $\mathrm{p}<.05$ olduğundan bu dağılım anlamlıdır. Dolayısıyla doktora tezlerinde yüksek lisans tezlerine göre daha çok içerik analizi yapılmakta olduğu yorumu yapılabilir. Son olarak yüksek lisans tezlerinin \%14.2'sinde; doktora tezlerinin ise $\% 25$ 'inde nonparametrik testler kullanılmıştır.

\section{9-Öğrenme alanı bakımından tezler nasıl bir dağılım göstermektedir?}

Matematik dersi sayılar ve işlemler, cebir, geometri ve ölçme, istatistik ve veri işleme öğrenme alanlarından oluşur (Talim Terbiye Kurulu 5-8 Matematik Dersi Öğretim Programı, 2013). İncelenen tezlerden bazıları bu öğrenme alanları dışında (Örn. Öğretim yöntemi, pedagoji, meta-analiz 
çalışmaları, matematiksel okuryazarlık vb.) bir alan üzerinde çalıştığından bu tezler "diğer" kategorisi altında gösterilmiştir.

Tablo 9. Öğrenme Alanlarına Göre Lisansüstü Tezlerin Sayıs1

\begin{tabular}{lccc}
\hline \multicolumn{1}{c}{ Öğrenme alanı } & Yüksek Lisans & Doktora & Toplam \\
\hline Sayılar ve işlemler & 60 & 8 & 68 \\
Cebir & 119 & 21 & 140 \\
Geometri ve ölçme & 97 & 25 & 122 \\
Veri işleme & 6 & 0 & 6 \\
Olasılık & 20 & 3 & 23 \\
Diğger & 188 & 55 & 243 \\
\hline
\end{tabular}

Tablo 9'a göre lisansüstü tezlerin 140'1 cebir alanında; 122'si geometri ve ölçme öğrenme alanında yazılmıştır. Ayrıca doktora tezlerinin hiç birinde veri işleme öğrenme alanı çalışılmadığı dikkat çekmektedir. Doktora tezlerinde daha çok belirli bir öğrenme alanından ziyade öğrenme alanlarına girmeyen (Örn. Pedagoji, ölçek oluşturma çalışmaları vb.) konular üzerinde odaklanılmıştır.

\section{0-Öğrenme alanı ile araştırma yaklaşımı arasında anlamlı bir dağılım var mıdır?}

Bu bölümde araştırma yaklaşımı olarak nitel, nicel ve karma olarak sınıflandırılan tezlerin, inceleme alanı ve öğrenme alanına yönelik ilişkilerine yer verilmektedir. Sayılar ve işlemler, cebir, geometri ve ölçme, veri işleme, olasılık olarak sınıflandırılan öğrenme alanlarının araştırma yaklaşımına göre incelenmesine ait bulgular Tablo 10'da sunulmuştur.

Tablo 10. Araştırma Yaklaşımı İle Öğrenme Alanı Çapraz Tablosu

\begin{tabular}{lcccc}
\hline Öğrenme Alanları & Nitel & Nicel & Karma & Toplam \\
\hline Sayılar ve İşlemler & 20 & 28 & 20 & 68 \\
Cebir & 44 & 49 & 47 & 140 \\
Geometri ve Ölçme & 60 & 23 & 39 & 122 \\
Veri İşleme & 3 & 3 & 0 & 6 \\
Olasıllk & 6 & 12 & 5 & 23 \\
Diğer & 95 & 79 & 69 & 243 \\
Toplam & 228 & 194 & 180 & 602 \\
\hline
\end{tabular}

Pedagoji, öğrenme stilleri, problem çözme, meta-analiz/meta-analitik çalışmaları, matematiksel okuryazarlık gibi Talim Terbiye Başkanlığı'nın 2013 yılında yayınladığı Ortaokul Matematik Dersi Öğretim Programı'nda yer alan 5 öğrenme alanı sınıflandırmasına girmeyen tezler, diğer kategorisi altında gösterilmiştir. Sınıflama sonucunda elde edilen Tablo 10'a göre "öğrenme alanlarından" en fazla (140 lisansüstü tez) cebir öğrenme alanında çalışıldığı görülmektedir. Veri işleme öğrenme alanında çok az (6 tez) çalışıldığı dikkat çekmektedir.

\section{1-Öğrenme alanı ile araştırma türü arasında anlamlı bir dağııım var mıdır?}

Tablo 11'de görüldüğü üzere betimsel olarak çalışılmış tezlerin çoğu(70 lisansüstü tez) geometri ve ölçme öğrenme alanındadır. Veri işleme öğrenme alanında yazılan 6 lisansüstü tezin 5'inin betimsel olarak yapıldığı dikkat çekmektedir. Ayrıca lisansüstü tezlerin üzerinde çalıştı̆̆ı öğrenme alanları ile tez türünün birbirinden bağımsız olmadıkları $(\mathrm{p}<.05)$ belirlenmiştir.

Tablo 11. Araştırma Türü ile Öğrenme Alanı Çapraz Tablosu

\begin{tabular}{lcccc}
\hline Öğrenme alanı & Betimsel & İlişkisel & Müdahaleli & Toplam \\
\hline Sayılar ve İşlemler & 41 & 4 & 23 & 68 \\
Cebir & 68 & 10 & 62 & 140 \\
Geometri ve Ölçme & 70 & 12 & 40 & 122 \\
Veri İşleme & 5 & 0 & 1 & 6 \\
Olasılık & 12 & 2 & 9 & 23 \\
Diğer & 159 & 36 & 48 & 243 \\
Toplam & 355 & 64 & 183 & 602 \\
\hline & & & & $\chi^{2}=32.363, \mathrm{sd}=10, \mathrm{p}=.000$
\end{tabular}




\section{2-Tezin yapıldığı üniversiteye göre öğrenme alanları nasıl bir dağılım göstermektedir?}

Üniversitelerin üzerinde yoğunlaştı̆g öğrenme alanları da alanyazın bakımından büyük önem taşıdığı düşünülmektedir. Nitekim bir üniversitenin çalışmaları genel anlamda cebirsel nitelikte mi, geometri ve ölçme niteliğinde mi yoksa diğer öğrenme alanlarının hangisi üzerinde olduğu üniversitenin çalışma alanı olarak künyesini ortaya koyacaktır. Üniversitelerin üzerinde yoğunlaştığı öğrenme alanları ise Tablo 12'de sunulmuştur.

Tablo 12. Öğrenme Alanlarına Göre Üniversitelerin Lisansüstü Tez Sayıları

\begin{tabular}{|l|c|c|c|c|c|c|c|}
\hline & $\begin{array}{c}\text { Say1lar ve } \\
\text { İ. }\end{array}$ & Cebir & Geometri & Veri İ. & Olas1lik & Diğer & Toplam \\
\hline 1.Gazi Ü. & $7.4 \%$ & $\mathbf{1 9 . 9 \%}$ & $\mathbf{1 4 . 8 \%}$ & $16.7 \%$ & $8.7 \%$ & $10.7 \%$ & $\mathbf{1 3 . 2 \%}$ \\
\hline 2.Marmara Ü. & $14.7 \%$ & $8.5 \%$ & $12.3 \%$ & $16.7 \%$ & $\mathbf{1 7 . 4 \%}$ & $8.6 \%$ & $10.4 \%$ \\
\hline 3.K. Teknik Ü. & $0.0 \%$ & $3.5 \%$ & $10.7 \%$ & $16.7 \%$ & $8.7 \%$ & $14.3 \%$ & $9.3 \%$ \\
\hline 4.Atatürk Ü. & $\mathbf{2 7 . 9 \%}$ & $9.2 \%$ & $3.3 \%$ & $16.7 \%$ & $13.0 \%$ & $4.9 \%$ & $8.6 \%$ \\
\hline 5.Dokuz Eylül Ü. & $1.5 \%$ & $12.1 \%$ & $13.1 \%$ & $0.0 \%$ & $0.0 \%$ & $7.0 \%$ & $8.4 \%$ \\
\hline 6.Gaziantep Ü. & $4.4 \%$ & $3.5 \%$ & $0.8 \%$ & $0.0 \%$ & $0.0 \%$ & $9.4 \%$ & $5.3 \%$ \\
\hline 7.ODTÜ & $4.4 \%$ & $7.1 \%$ & $1.6 \%$ & $16.7 \%$ & $8.7 \%$ & $4.1 \%$ & $4.6 \%$ \\
\hline 8.N. Erbakan Ü. & $1.5 \%$ & $5.7 \%$ & $4.1 \%$ & $0.0 \%$ & $4.3 \%$ & $5.3 \%$ & $4.6 \%$ \\
\hline 9.Osmangazi Ü. & $0.0 \%$ & $3.5 \%$ & $2.5 \%$ & $0.0 \%$ & $4.3 \%$ & $5.3 \%$ & $3.6 \%$ \\
\hline 10.Balıkesir Ü. & $2.9 \%$ & $4.3 \%$ & $0.8 \%$ & $0.0 \%$ & $0.0 \%$ & $5.3 \%$ & $3.6 \%$ \\
\hline
\end{tabular}

Tablo 12'de görüldüğü üzere sayılar ve işlemler öğrenme alanında yazılan tezlerin \%27.9'u Atatürk Üniversitesi bünyesinde; cebir öğrenme alanında yazılan tezlerin \%19.9'u Gazi Üniversitesi bünyesinde; geometri ve ölçme alanında yazılan tezlerin \%14.8'i yine Gazi Üniversitesi bünyesinde ve olasılık ögrenme alanında yazılan tezlerin \%17.4'ü Marmara Üniversitesi bünyesinde yapılmıştır. $\mathrm{Bu}$ anlamda sayılar ve işlemler öğrenme alanı üzerinde Atatürk Üniversitesi'nin; cebir ile geometri ve ölçme öğrenme alanları üzerinde Gazi Üniversitesi'nin; olasılık öğrenme alanı üzerinde Marmara Üniversitesi'nin diğer üniversitelere göre daha yoğun çalıştığı söylenebilir.

\section{3-Yıllara göre öğrenme alanları nasıl bir dağılım göstermektedir?}

Aşağıdaki tabloda ise yıllara göre öğrenme alanı bazında trendler sunulmuştur.

Tablo 13. Yıllara Göre Öğrenme Alanı Bazında Lisansüstü Tez Sayıları

\begin{tabular}{|l|c|c|c|c|c|c|c|c|}
\hline & 2010 & 2011 & 2012 & 2013 & 2014 & 2015 & 2016 & Toplam \\
\hline Sayılar ve İşlemler & 11 & 4 & 12 & 18 & 8 & 8 & 7 & 68 \\
\hline Cebir & $\mathbf{2 8}$ & 19 & $\mathbf{2 7}$ & 23 & $\mathbf{1 9}$ & 12 & 12 & $\mathbf{1 4 0}$ \\
\hline Geometri ve Ölçme & 20 & $\mathbf{2 0}$ & 14 & $\mathbf{2 4}$ & 12 & $\mathbf{1 8}$ & $\mathbf{1 4}$ & 122 \\
\hline Veri İşleme & 2 & 0 & 0 & 1 & 2 & 1 & 0 & 6 \\
\hline Olasılık & 6 & 1 & 3 & 7 & 3 & 1 & 2 & 23 \\
\hline Diğer & 23 & 39 & 44 & 55 & 29 & 31 & 22 & 243 \\
\hline Toplam & 90 & 83 & 100 & 128 & 73 & 71 & 58 & 602 \\
\hline
\end{tabular}

Tablo 13'te görüldüğü üzere 5 öğrenme alanı ve 1 diğer kategorisi bulunmaktadır. Belli bir öğrenme alanı altına girmeyen dokuman incelemesi, pedagoji, öğretim yöntem ve teknikleri gibi konular üzerinde çalışılan tezler diğer kategorisi altında sınıflandırılmıştır. Öğrenme alanı içerisinde kategoriler altında sınıflandırılan tezler incelendiğinde 2010 y1lında \%31.1 oranla cebir alanı, 2011 yılında $\% 24.1$ oranla geometri ve ölçme alanı, 2012 yılında $\% 27$ oranla cebir alanı, 2013 yılında $\% 18.8$ oranla geometri ve ölçme alanı, 2014 yılında \%26 oranla cebir alanı, 2015 y1lında \%25.4 oranla geometri ve ölçme alanı ve 2016 yılında \%23.7 oranla geometri ve ölçme alanı üzerinde yoğunlaşılan trend alanlar olmuştur. 


\section{Tartışma}

Alanyazında bu araştırmaya yakın bazı çalışmalar bulunmaktadır. Bunlardan ikisi yüksek lisans tezi, (Yücedağ, 2010; İlhan, 2011) diğer ikisi Çiltaş vd. (2012); Ulutaş ve Ubuz (2008) tarafından yapılan çalışmadır. Bu araştırmanın bulguları, alanyazındaki çalışma bulgu ve sonuçları ile karşılaştırılmıştır. Matematik eğitimi alanında lisansüstü çalışmaların tematik yönden 2010'dan önce ve 2010'dan sonraki değişimi ortaya konulmuştur.

$\mathrm{Bu}$ araştırmanın bulgularına göre matematik eğitimi alanında yazılan son 7 yılda erişime açık 602 tezin \%81.40'ını yüksek lisans, \%18.60'ını doktora tezleri oluşturmaktadır. Bu durum Yücedağ (2010) çalışması ile karşılaştırılınca 2010 yılından sonra doktora tezlerinin oranının arttığı görülmektedir. Ayrıca yüksek lisans tezlerinin son yıllarda azalma eğilimi gösterdiği ve yıllara göre yüksek lisans tez sayısında büyük dalgalanma olduğu görülmüştür. Doktora tezlerinin sayısında ise dalgalanma, yüksek lisans tezlerinde görülen dalgalanmaya göre azdır.

Üniversitelere göre lisansüstü tezler incelendiğinde en üretken üniversitenin Gazi Üniversitesi olduğu görülmüştür (62 yüksek lisans ve 18 doktora tezi olmak üzere toplam 80 lisansüstü tez). Bu bulgu Yücedă̆ (2010) çalışmasıyla paralellik göstermektedir. Gazi Üniversitesi 2000-2009 yılları arasında 69 lisansüstü tez ile matematik eğitimi alanında en fazla lisansüstü tez yazılan üniversite olmuştur.

İncelenen tezlerde araştırma yaklaşımı olarak en fazla nitel araştırma kullanıldığ görülmüştür. Doktora tezlerinde nicel araştırma yaklaşımının az kullanılması dikkat çekmiştir. Araştırmacılar doktora tezlerinde daha çok nitel ve nicel yöntemlerin birlikte kullanıldığı karma yöntemler ile çalışmışlardır. Bu durumun nedeni olarak doktora tezlerinin daha detaylı bilgilere ulaşmak amacı olduğu düşünülmektedir. Çiltaş vd. (2012) tarafından yapılan çalışmaya göre 1987 ile 2009 yılları arasında yapılan çalışmalarda karma yöntem çok az kullanılmıştır (\%5.3). Son yıllarda yapılan çalışmalara bakıldığında ise özellikle sosyal bilimler alanında karma araştırmaların sayısının arttığı görülmektedir (Gökçek, Babacan, Kangal, Çakır ve Kül, 2013). Bu araştırmanın bulgularına göre yüksek lisans tezlerinin $\% 26.3$ 'ü, doktora tezlerinin ise $\% 45.5$ ' $\mathrm{i}$ karma yöntemlerle yazılmıştır. Karma yöntem araştırmaya zenginlik ve güvenilirlik katmak amacıyla tercih edilmektedir (Gökçek vd., 2013). $\mathrm{Bu}$ nedenle yüksek lisans tezlerinden daha detaylı bir içeriğe sahip ve uzmanlık alanı niteliği taşıyan doktora tezlerinde karma araştırma yönteminin daha çok kullanıldığı görülmektedir.

Tez yazarının cinsiyeti ile tez türü (YL/doktora) arasında istatistiksel olarak anlamlı bir ilişki olduğu belirlenmiş̧ir. Bu bulguya göre yüksek lisans yazarlarının daha çok kadınlar olduğu söylenebilir. Bu konuda daha önce yapılmış çalışma bulguları göz önüne alındığında (Yücedağ, 2010) kadınların sayısında artış olduğu görülmektedir. Ancak kadın araştırmacıların yüksek lisans eğitimlerinden sonra doktoraya eğitimlerine devam etme oranı düşmüştür. Bu durumun nedeninin evlilik, çalışma zorluğu ve doktora eğitiminin daha detaylı ve uğraş verilmesi gereken eğitim olduğu düşünülmektedir.

Öğrenme alanı olarak en fazla cebir alanında çalışma yapıldığı görülmüştür. Bu durum 2010 öncesi alanyazında da kendini göstermiştir. 1987-2009 yılları arasındaki makalelerde cebir alanı daha fazla çalışılmıştır (Çiltaş vd., 2012). Ancak 2010 ve sonrasında geometri ve ölçme alanındaki çalışmaların sayısal olarak cebir alanında yapılan çalışmalara yaklaştığı görülmektedir. Bunların yanı sıra bilimsel araştırmaya temel sayılabilecek "veri işleme" öğrenme alanı üzerinde çalışmaların az yapılması alanyazında önemli bir eksiklik olarak düşünülmektedir.

Öğrenme alanları ile araştırma türü arasındaki kontenjans tablosuna bakıldığında geometri ve ölçme alanında çalışılan tezlerin genellikle nitel yöntem ile yapıldığı görülmektedir. Bu nedenle geometri ve ölçme alanında yapılan çalışmalarda nitel yöntemlerin kullanılmasının alanyazındaki teorik bilgilere uygun düştügü düşünülmektedir.

İncelenen tezlerde uygulanan bir öğretim yöntemi ya da materyalinin öğrencilerin derse karşı tutumu, ilgisi, kaygısı gibi duyuşsal özellikleri üzerindeki etkisine yönelik çalışmaların azlığı dikkat çekmektedir. Öğrenme alanı olarak veri işleme alanında yapılan çalışmaların hemen hepsi (6 çalışmanın 5'i) betimsel niteliktedir. Veri işleme ile deneysel ve ilişkisel lisansüstü araştırmalarının yapılmaması/çok az olması alanyazında bir eksiklik olarak düşünülmektedir. 
Araştırma bulgularına göre örneklem olarak yüksek lisans tezlerinde öğrencilerin daha çok kullanıldığı $(\mathrm{p}<.05)$, doktora tezlerinde ise yüksek lisans tezlerine göre doküman ve öğretmen adayları örneklem olarak daha çok kullanıldığı $(\mathrm{p}<.05)$ belirlenmiştir. Araştırma bulgularına göre dikkat çeken şey yöneticiler üzerinde Matematik Eğitimi Bilim Dalı'nda araştırma yapılmamış olmasıdır. Bu durum alanyazında eksiklik olarak düşünülmektedir.

Veri toplama aracı olarak gözlem, görüşme ve dokuman kullanımı yüksek lisans tezlerine göre doktora tezlerinde daha fazla kullanılmıştır ve bu fark anlamlıdır $(\mathrm{p}<.05)$. Gözlem ve görüşme formu nitel veri toplama araçları olup derinlemesine objektif bilgi edinmeyi sağlar (Arıkan, 2013). Bu nedenle doktora tezlerinin yüksek lisans tezlerine göre daha kapsamlı bilgilere ulaştığı sonucuna ulaşılabilir. Ayrıca İlhan (2008)'ın çalışmasına göre 2005-2009 y1lları arasında ulusal lisansüstü tezlerde veri toplama aracı olarak en fazla (\%30.5) ölçek kullanılmıştır. Ölçekten sonra ise veri toplama aracı olarak \%24.6 oranıyla başarı testleri kullanılmıştır. 2010-2017 yılları arasındaki lisansüstü tezlerde ise başarı testi kullanım oranı \%50'ye kadar yükselmiştir. Bu durum öğrenci başarısı üzerinde yapılan çalışmaların arttı̆̆ının göstergesidir.

İstatistiksel teknik olarak içerik analizi tekniği doktora tezlerinde yüksek lisans tezlerine göre daha çok kullanılmıştır ve bu fark anlamlıdır $(\mathrm{p}<.05)$. Ayrıca yüksek lisans tezleri içerisinde en fazla betimsel istatistik, doktora tezleri içerisinde ise en fazla betimsel analiz ve içerik analizi kullanılmıştır. Doktora tezlerinde birden fazla istatistiksel teknik kullanıldığı dikkat çeken başka bir husus olmuştur. Yıldırım ve Şimşek (2013)'e göre betimsel analizle yorumlanan veriler içerik analizine tabi tutulursa daha derin yorumlamalar yapılabilir ve betimsel analizle fark edilemeyen temalar keşfedilebilir. Buna göre doktora tezlerinde yüksek lisans tezlerine göre betimsel istatistiğin yanında içerik analizi tekniğinin de kullanılması araştırmanın daha derin nitelikte olduğunu gösterir. Ayrıca İlhan (2008)'ın çalışmasına göre 2005-2009 yılları arasında ulusal lisansüstü tezlerde veri analiz yöntemi olarak en fazla t-test (\%24.7) kullanılmıştır. T-testi kullanımını \%21.1 oranıyla betimsel istatistik, \%13.1 oranıyla ANOVA kullanımı takip etmektedir. 2010 yllından itibaren ise \%49.4 oranıla en fazla betimsel istatistik kullanılmıştır.

Genel olarak Türkiye'de 2000'lerden sonra matematik eğitimindeki araştırmaların arttı̆̆ görülmüştür. $\mathrm{Bu}$ durumun 2000'li yılların başında yurtdışı doktora eğitiminden dönen akademisyenlerden kaynaklandığı düşünülmektedir. Ayrıca 2016 yılı itibariyle tez sayısı olarak 2010 yılına geri dönüş dikkat çekmiştir. Ülkemizde tarihsel süreç içerisinde matematik eğitimi araştırmalarının bilişsel boyutta olduğu ve cebir ve geometri alanlarında yoğunlaşıldığı görülmektedir. Bu alanlarda yapılan çalışmalarda başarı testlerinin yoğun olarak kullanılması da ülkemizdeki matematik eğitimi araştırmalarının genel özellikleri olduğu düşünülmektedir.

\section{Sonuç ve Öneriler}

Araştırmanın bulgularının değerlendirilmesinden sonra genel olarak matematik eğitimi alanında yazılan lisansüstü tez sayılarının dalgalanma gösterdiği, özelde ise bu dalgalanmanın yüksek lisans tez sayılarında fazla olduğu görülmüştür. 2016 yılı itibariyle yüksek lisans tez sayının azalma eğiliminde olduğu araştırma sonucunda ulaşılan başka bir sonuç olmuştur.

Son yıllarda yapılan lisansüstü tezler araştırma türü bakımından nitel yöntemler ile yazıldığı dikkat çekse de karma yöntemlerin eğitim araştırmalarında olduğu gibi matematik eğitimi araştırmalarında da sayısının arttığı görülmüştür.

Örneklem olarak yöneticiler üzerinde herhangi bir çalışmaya rastlanmamış olması ilgili alanyazındaki eksikliği göstermektedir. Okul yöneticilerinin matematik eğitimine bakış açıları, matematik eğitimine yönelik pozitif ayrımcılık (matematik sınıfı, matematik laboratuvarı oluşturma gibi) kararları araştırmaya değer alanlar olabilir. Ayrıca branşı bakımından matematik öğretmeni olan yöneticiler üzerinde okulun genel matematik kültürü ve matematik başarısının arttırılmasına yönelik görüşleri, okul uygulamaları, matematik dersine yönelik bakış açıları ve okulda matematik araç-gereçlerinin sağlanması yönünde hassasiyetler gibi konular araştırılabilir. Araştırmacıların yapacağ 1 bu tür 
çalışmaların alanyazında önemli bir boşluğu dolduracağı açıktır. Bu nedenle araştırmacıların bu konularda çalışma yapabilecekleri önerilmektedir.

Araştırmanın bir başka dikkat çeken sonucunu ise "veri işleme" öğrenme alanı üzerinde çok fazla lisansüstü çalışma bulunmaması oluşturmaktadır. Bilimsel araştırmanın temeli sayılabilecek ve gerekli temel bilgilerin oluştuğu veri işleme alanında çalışmaların çok az sayıda yapılması alanyazındaki diğer bir eksikliği gösterdiği düşünülmektedir. Araştırmanın diğer bir sonucu olarak yüksek lisans tezlerinde istatistiksel tekniklerin sayıca azlığı dikkat çekmiştir. Genel anlamda betimsel istatistiğin kullanıldığ yüksek lisans tezlerinde genel bir durum resmedilmiş ve değişkenler arası ilişkiye çok az bakılmıştır.

Veri toplama aracı olarak gözlem, görüşme ve doküman incelenmesinin kullanılmasının araştırmaya derinlik katacağı düşünülmektedir. Bu durumun doğrulayıcısı olarak doktora tezlerinde genel olarak veri toplama aracı olarak gözlem, görüşme ve dokuman incelemesi kullanılması gösterilebilir.

Son olarak belli bir alanda yapılan yayınların ele alınacağı meta-analitik çalışmaların yapılması önemli bir araştırma konusu olarak öne çıkmaktadır. Daha önce yapılan meta-analiz/meta-analitik çalışmaları incelendiğinde incelenen araştırma ve çalışmaların genel bir resmi ortaya konulmuş olup değişkenler arasında anlamlı bir ilişkinin olup olmadığına bakılmamıştır. Bundan sonraki yapılacak meta-analitik çalışmalarda araştırmacılara değişkenler arasında anlamlı bir ilişkinin bulunup bulunmamasına yönelik ki-kare testlerinin kullanılması önerilebilir. Ayrıca 2010 yılı itibariyle matematik eğitimi alanında dergilerde yayınlanan makalelerin incelenmesi araştırmacılara önerilebilir.

\section{Kaynakça}

Ahi, B., \& Kıldan, A. O. (2013). Türkiye'de okul öncesi eğitimi alanında yapılan lisansüstü tezlerin incelenmesi(2002-2011). Mehmet Akif Ersoy Üniversitesi Ĕ̈itim Fakültesi Dergisi, 27, 23-46.

Arıkan, R. (2013). Araştırma yöntem ve teknikleri (2.Bask1). Ankara: Nobel Yayınları.

Ayaz, M. F., \& Söylemez, M. (2015). Proje tabanlı öğrenme yaklaşımının Türkiye'deki öğrencilerin fen derslerindeki akademik başarılarına etkisi: bir meta-analiz çalışması. Eğitim ve Bilim Dergisi, 178(40), 255-283. Doi: 10.15390/EB.2015.4000.

Ayaz, M. F., \& Şekerci, H. (2015). Yapılandırmacı öğrenme yaklaşımının akademik başarıya ve tutuma etkisi: bir meta-analiz çalışması. Hasan Ali Yücel Eğitim Fakültesi Dergisi, 24(12-2), $27-44$.

Baki, A., Güven, B., Karataş, İ., Akkan, Y., \&Çakıroğlu, Ü. (2011). Türkiye'deki matematik eğitimi araştırmalarındaki eğilimler: 1998 ile 2007 yılları arası. Hacettepe Üniversitesi Eğitim Fakültesi Dergisi, 40, 57-68.

Batdı, V. (2014). Etkinlik Temelli Öğrenme Yaklaşımının Akademik Başarıya Etkisi (Meta-analitik ve tematik Bir çalişma)/The Effect of Activity-Based Learning Approach on Academic Achievement (A Meta-Analytic and Thematic Study). e-International Journal of Educational Research, 5(3).

Bozan, M. (2012). Lisansüstü eğitimde nitelik arayışları. Sosyal ve Beşeri Bilimler Dergisi, 2(4), 177 187.

Büyüköztürk, Ş., Çakmak K.Ç., Akgün Ö.E, Karadeniz, Ş., \& Demirel, F. (2010). Bilimsel araştırma yöntemleri (6. Bask1). Ankara: Pegem Akademi.

Crombie, I. K., \& Davies, H. T. (2009). What is meta-analysis. What is ...? series, second edition. Hayward Publication. [Internet-21.08.2014].

http://www.medicine.ox.ac.uk/bandolier/painres/download/whatis/meta-an.pdf

Çarkungöz, E., \& Ediz, B. (2009). Meta analizi. Uludă̆ Üniversitesi Veteriner Fakültesi Dergisi, 28(1), 33-37. 
Çelik, S. (2013). İlköğretim matematik derslerinde kullanılan alternatif öğretim yöntemlerinin akademik başarıya etkisi: bir meta analiz çalışması.(Yayımlanmamış yüksek lisans tezi). Eskişehir Osmangazi Üniversitesi Eğitim Bilimleri Enstitüsü. Eskişehir.

Çiltaş, A., Güler, G., \& Sözbilir, M. (2012). Türkiye'de matematik eğitimi araştırmaları: bir içerik analizi çalışması. Kuram ve Uygulamada Ĕgitim Bilimleri Dergisi, 12(1), 565-580.

Göktaş, Y. Küçük, S., Aydemir, M, Telli, E., Arpacık, Ö., Yıldırım, G., \& Reisoğlu, İ. (2012). Türkiye'de eğitim teknolojileri araştırmalarındaki eğilimler: 2000-2009 dönemi makalelerinin içerik analizi. Kuram ve Uygulamada Eğitim Bilimleri, 12(1), 177-179.

Ilıman Püsküllüoğlu, E., \& Hoşgörür, V. (2017). Türkiye'de 2010-2016 yılları arasında yapılan karş1laştırmalı eğitim lisansüstü tezlerinin değerlendirilmesi. Muğla Sitkı Koçman Üniversitesi Eğitim Fakültesi Dergisi, 4(1), 46-61. Doi: 10.21666/muefd.304009

İlhan, A. (2011). Matematik eğitimi araştırmalarında tematik ve metodolojik eğilimler:uluslararası bir çözümleme. (Yayımlanmamış yüksek lisans tezi). Eskişehir Osmangazi Üniversitesi Eğitim Bilimleri Enstitüsü. Eskişehir.

Karaca, E., Yurdabakan, İ., Çetin, B., Nartgün, Z., Bıçak, B., \& Gömleksiz, M. (2010). Eğitimde Ölçme ve Değerlendirme (2. Baskı). Ankara: Nobel Yayınevi.

Karaman, S. ve Bakırcı, F. (2010). Türkiye'de lisansüstü eğitim: sorunlar ve çözüm önerileri. Sosyal Bilimler Araştırmaları Dergisi, 2, 94-114.

Karamustafaoğlu, O. (2009). Fen ve teknoloji eğitiminde temel yönelimler. Kastamonu Eğitim Dergisi, 17(1), 87-102.

Karkın, A.M. (2011). Müzik bilimleri alanında yapılan lisansüstü tezlerin incelenmesi. İnönü Üniversitesi Sanat ve Tasarım Dergisi, 2(1), 143-149.

Kaşarcı, İ. (2013). Proje tabanlı ögrenme yaklaşımının ögrencilerin akademik başarı ve tutumlarına etkisi: bir meta-analiz çalışması. Yayınlanmamış yüksek lisans tezi, Eskişehir Osmangazi Üniversitesi Eğitim Bilimleri Enstitüsü.

Kaya, M.F. (2013). Coğrafya eğitiminde yönelimler: 2012 yılına kadar yapılan lisansüstü tezler üzerinde bir meta-analiz çalışması. Marmara Coğrafya Dergisi, 14, 282-313.

Küçük, H., \& Aycan, H. (2014). 2007-2012 Yı1ları arasında bilimsel tartışma üzerine gerçekleştirilmiş açık erişim araştırmaların bir incelemesi. Muğla Sıtkı Koçman Üniversitesi Eğitim Fakültesi Dergisi, l(1) . DOI: 10.21666/mskuefd.05345.

M.E.B. (Milli Eğitim Bakanlığı Talim ve Terbiye Kurulu Başkanlığı). (2013). Ortaokul matematik dersi ögretim programı. Ankara: MEB.

M.E.B. (Ölçme, Değerlendirme ve Sınav Hizmetleri Genel Müdürlüğü). (2016). Uluslararası öğrenci değerlendirme programı PISA 2015 değerlendirme raporu. Ankara: MEB.

Nacar, S. (2015). 2005-2014 yılları arasında üstün yeteneklilerin matematik eğitimi üzerine yapılan çalışmalar. (Yayımlanmamış yüksek lisans tezi). İnönü Üniversitesi Eğitim Bilimleri Enstitüsü. Malatya.

Özenç, M., \& Özenç, E.G. (2013). Türkiye'de üstün yetenekli öğrencilerle ilgili yapılan lisansüstü eğitim tezlerinin çok boyutlu olarak incelenmesi. Türkiye'de Sosyal Araştırmalar Dergisi, 171, $13-28$

Serin, T., \& Turan, E.D. (2015). Yunus Emre Türkçe öğretimi setinde yer alan metinlerin tür, tema ve özgünlük bakımından incelenmesi. Uluslararası Türkçe Edebiyat Kültür Eğitim Dergisi, 4(3), 1229-1250. 
Şahin, D., Calp, Ş., Bulut, P., \& Kuşdemir Y. (2013). Sınıf öğretmenliği eğitimi bilim dalında yapılmış lisansüstü tezlerin çeşitli kriterlere göre incelenmesi. Zeitschrift für die Welt der Türken, 5(3), 187-205.

Tarman, B., Acun, İ., \& Yüksel, Z. (2010). Sosyal bilgiler eğitimi alanındaki tezlerin değerlendirilmesi. Gaziantep Üniversitesi Sosyal Bilimler Dergisi, 9(3), 725-746.

Ulutaş, F., \& Ubuz, B. (2008). Matematik eğitiminde araştırmalar ve eğilimler: 2000 ile 2006 yılları aras1. Illköğretim Online, 7(3), 614-626.

Yıldırım, A., \& Şimşek, H. (2013). Sosyal bilimlerde nitel araştıra yöntemleri (9. Baskı). Ankara: Seçkin Kitabevi.

Yücedă̆, T. (2010). 2000-2009 yılları arasında matematik eğitimi alanında Türkiye'de yapılan çalışmalarının bazı değişkenlere göre incelenmesi. (Yayımlanmamış yüksek lisans tezi). Selçuk Üniversitesi Eğitim Bilimleri Enstitüsü. Konya. 